\title{
A Case Report of Real-Time in vivo Demonstration of Sarcoptes scabiei
}

Sarcoptes scabieı nin Gerçek Zamanlı in vivo Olarak Gösterildiği Bir Olgu Sunumu

\author{
Mehmet Salih Gürel', Aslı Vefa Turgut Erdemir², Burak Tekin¹ \\ ${ }^{1}$ Clinic of Dermatology, İstanbul Medeniyet University, Göztepe Training and Research Hospital, İstanbul, Turkey \\ ${ }^{2}$ Clinic of Dermatology, İstanbul University Training and Research Hospital, İstanbul, Turkey
}

Cite this article as: Gürel MS, Turgut Erdemir AV, Tekin B. A Case Report of Real-Time in vivo Demonstration of Sarcoptes scabiei. Türkiye Parazitol Derg 2017; 41: 229-32.

\section{ABSTRACT}

Scabies is a pruritic dermatosis caused by the ectoparasite Sarcoptes scabiei var. hominis. The diagnosis of scabies is usually made on clinical grounds, but histopathological and/or dermoscopic examinations may sometimes be of assistance. However, these diagnostic modalities do not offer a detailed in vivo demonstration of the motile microorganism. Reflectance confocal microscopy (RCM) is a relatively novel imaging modality that permits in vivo examination of the skin at a resolution similar to that used during similar to histopathologic resolution. Here, a patient with crusted scabies is presented in whom a brief section of the lifecycle of S. scabiei was captured by RCM. Using this advanced imaging modality, the ectoparasite's motion within the human host can be examined for clinical or research purposes and the mite's viability may be assessed to monitor the response to treatment.

Keywords: Crusted scabies, reflectance confocal microscopy, Sarcoptes scabiei

Received: 30.05 .2017

Accepted: 11.10 .2017

\section{Öz}

Uyuz, Sarcoptes scabiei var. hominis ektoparazitinin etken olduğu kaşıntılı bir dermatozdur. Uyuz tanısı genellikle klinik olarak konulmaktadır; histopatolojik ve/veya dermoskopik inceleme tanıya yardımcı olabilir, ancak bu iki tanı yöntemi de, hareketli mikroorganizmanın in vivo olarak detaylı gösterilmesine olanak sağlamamaktadır. Reflektans konfokal mikroskopi (RKM), derinin histopatolojik incelemeye yakın bir çözünürlükte in vivo olarak incelenmesine imkân sağlayan, görece yeni bir görüntüleme yöntemidir. Burada, RKM ile Sarcoptes scabiei'nin yaşam siklusundan kısa bir kesitin kaydedildiği bir krutlu uyuz hastası sunulmaktadır. Bu gelişmiş görüntüleme yöntemi kullanılarak, ektoparazitin konağı olan insandaki hareketi klinik uygulamalar veya araştırma amacıyla incelenebilir ve akarın canlılığı, tedavi yanıtını takip etmek için değerlendirilebilir.

Anahtar Kelimeler: Krutlu uyuz, reflektans konfokal mikroskopi, Sarcoptes scabiei

Geliş Tarihi: 30.05.2017

Kabul Tarihi: 11.10.2017

\section{INTRODUCTION}

Scabies is a pruritic dermatosis that is caused by the ectoparasite Sarcoptes scabiei var. hominis. During its life cycle, the adult female mite excavates a burrow and deposits eggs within the superficial layers of the epidermis (1). Classically, the burrows are localized on the interdigital areas, wrists, nipples, axillae, buttocks, and penile shaft (2). Pruritus, which is the hallmark symptom of scabies, is more intense at night and is believed to be due to an inflammatory reaction against the mite and its feces. In addition to the classical form, there is a rare, yet well-defined form of scabies known as "crusted scabies," which is characterized by the massive proliferation of mites on the skin surface of the host. This entity is usually seen in patients with an underlying condition, causing an immunosuppressed state, and may pose a challenge for clinicians due to its varied cutaneous presentation $(3,4)$.

Scabies is generally diagnosed based on clinical features, and histopathological confirmation is rarely required. Mites, eggs, or fecal pellets can be identified using light

Address for Correspondence / Yazışma Adresi: Mehmet Salih Gürel, E.mail: msgurel@gmail.com DOI: $10.5152 /$ tpd.2017.5408

(C) Copyright 2017 Turkish Society for Parasitology - Available online at www.tparazitolderg.org

OTelif hakkı 2017 Türkiye Parazitoloji Derneği - Makale metnine www.tparazitolderg.org web sayfasından ulaşılabilir. 


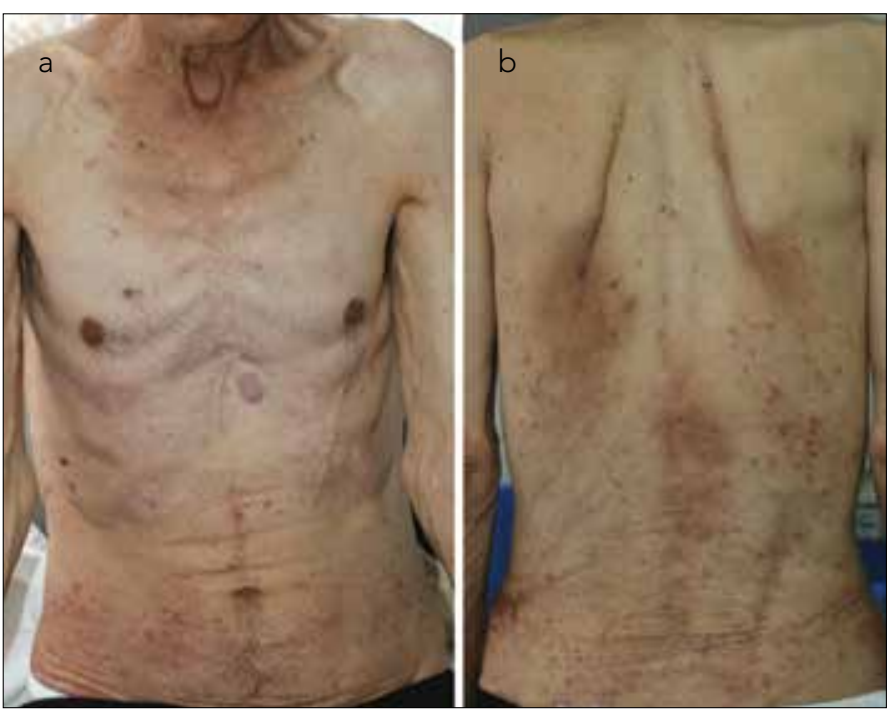

Figure 1. a-b. Numerous excoriated erythematous papules on the anterior (a) and posterior (b) aspect of the trunk

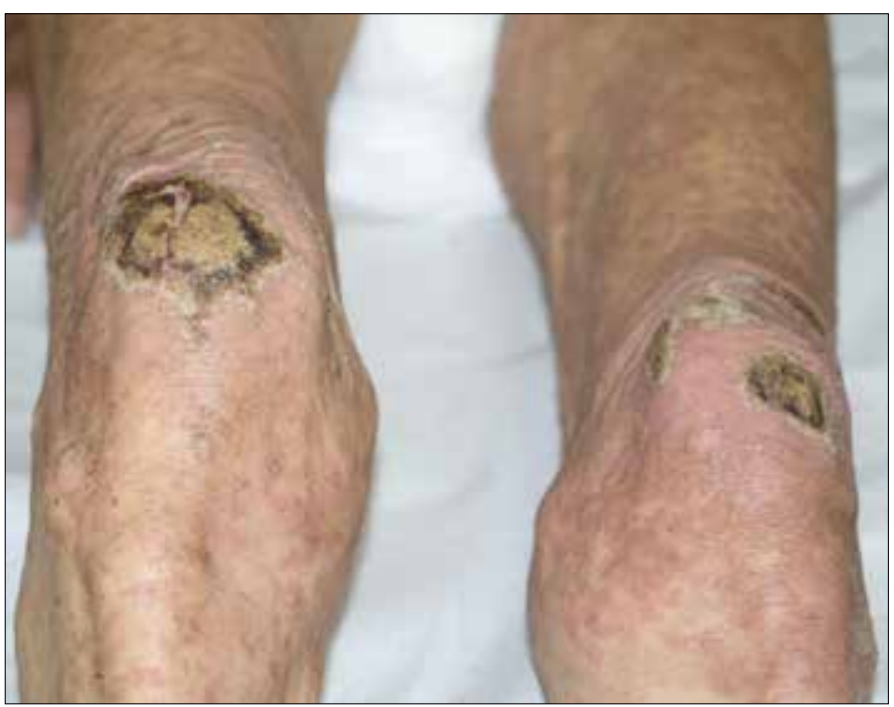

Figure 2. Hyperkeratotic plaques on the extensor surfaces of the knees on a diffuse background of erythematous, scaly, excoriated, and somewhat lichenoid papules

microscopy for making a definitive diagnosis (1). Epiluminescence microscopy/dermoscopy may also be useful diagnostic adjuncts. Besides light microscopy and dermoscopy, $S$. scabiei can be visualized using reflectance confocal microscopy (RCM), which is an imaging modality that allows in vivo examination of the skin at a resolution similar to that used during histopathology $(2,4,5)$. As a light source, this technique employs a diode laser and combines the advantage of being non-invasive with the ability to study dynamic events occurring within various layers of the skin. Detection of S. scabiei using RCM has been described by some authors in the literature (4-11). However, to the best of our knowledge, the examination of $S$. scabiei with RCM in real-time video format has not been reported in Turkey. Here we report the case of a patient with crusted scabies and demonstrate a brief portion of the lifecycle of the ectoparasite.

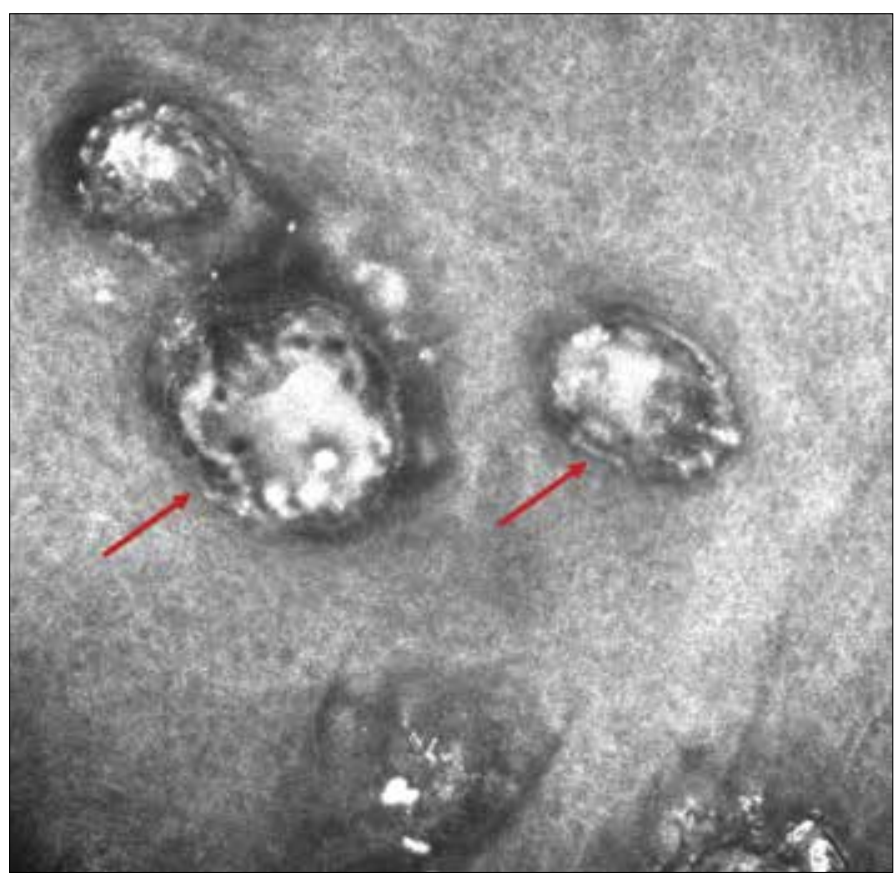

Figure 3. Sarcoptes scabiei mites on reflectance confocal microscopy (red arrows)

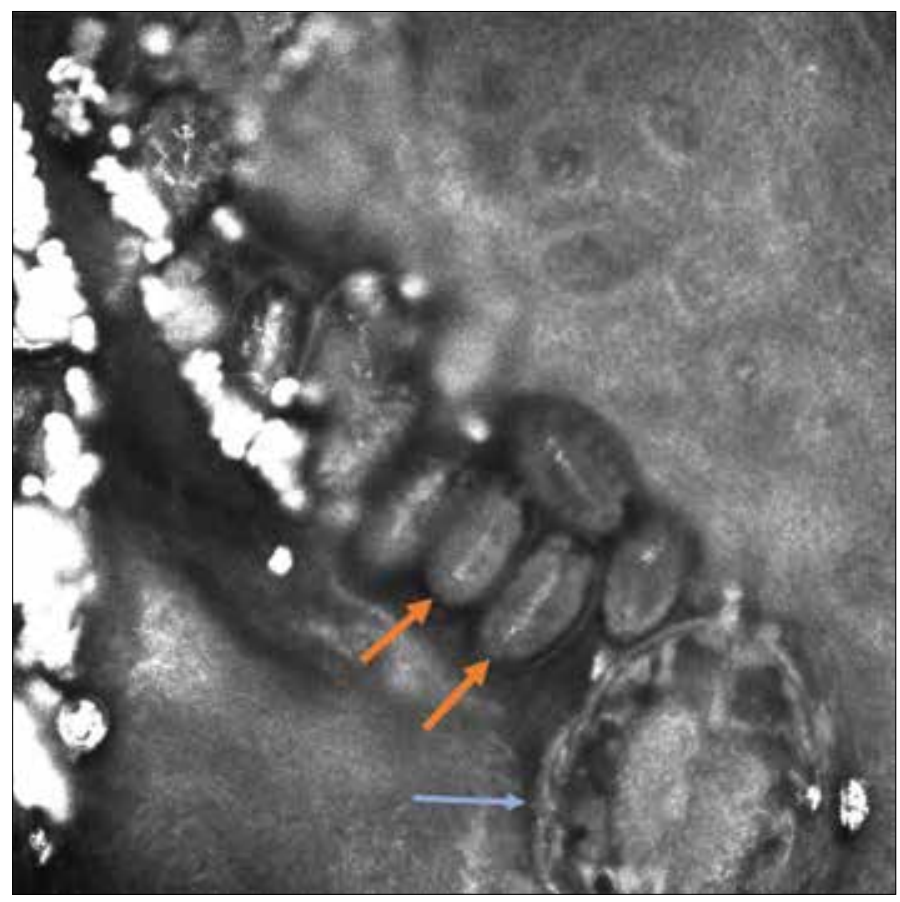

Figure 4. At the end of the burrow, a Sarcoptes scabiei mite (blue arrow) was visualized, accompanied by multiple eggs (orange arrows) and feces (highly refractive structures)

\section{CASE REPORT}

A 71-year-old male presented with a one-year history of severe pruritus that was reportedly more bothersome at night. He had previously undergone multiple histopathological and systemic evaluations and had received various topical treatments including potent corticosteroids; however, they did not show any significant improvement. He was admitted to the dermatology depart- 
ment for further evaluation. A physical assessment failed to reveal any signs of malignancy, and his viral serology tested negative. A cutaneous examination revealed widespread erythematous and excoriated papules on the trunk and extremities (Figure 1). In addition, hyperkeratotic plaques on an erythematous background were noted on the interdigital spaces and the extensor surfaces of the knees (Figure 2). Dermoscopy revealed structures resembling mites. After informed consent was obtained from the patient, different areas of the patient's body were examined using RCM (Vivascope 3000, Lucid Inc., Henrietta, NY, USA) after scraping off the scales. Images from different horizontal sections of the skin were captured and analyzed, and a burrow with multiple mites was identified immediately underneath the stratum corneum (Figure 3). Furthermore, a motile mite was detected at the distal end of the burrow, whereas more mature larvae were identified at the proximal end of the same burrow; these larvae were accompanied by hyperdense-appearing feces (Figure 4, Video 1). Based on clinical features and findings of RCM, the patient was diagnosed as having crusted scabies. Accordingly, he was treated with topical permethrin cream in combination with oral ivermectin $(0.2 \mathrm{mg} / \mathrm{kg} /$ week; $15 \mathrm{mg} /$ week; patient weight $75 \mathrm{~kg}$ ), with the same dose repeated a week later. At the twoweek follow-up, the scales of the lesions had mostly disappeared and the number and infiltration of the papules had markedly decreased. In addition, remarkable improvement was noted in the severity of pruritus.

\section{DISCUSSION}

We presented the case of a patient with a challenging diagnosis of crusted scabies in whom RCM assisted in the diagnostic workup. Classically, the diagnosis of scabies is straightforward and is based on clinical grounds; however, crusted scabies in particular may pose a diagnostic challenge $(1,3)$. In the presented case, it is speculated that long-term treatment with potent topical corticosteroids for almost a year, together with the age of the patient, caused a relatively immunosuppressed state, influencing the cutaneous phenotype and giving rise to a challenging clinical presentation of crusted scabies.

Reflectance confocal microscopy is a relatively novel optical imaging modality that offers several important advantages over conventional diagnostic techniques. First, it is non-invasive, obviating the need for tissue processing and staining. Second, high-resolution images can be obtained from different layers of the skin, allowing for a detailed examination of cutaneous changes at various depths. In addition, RCM enables the monitoring of dynamic changes in the skin in real time, which greatly expands the potential utility of this technique. However, RCM has two major drawbacks; it may be considered to be relatively time consuming, and may be difficult to implement on hardto-reach body areas such as the genital region. However, the advent of a hand-held device has partially circumvented these problems. More importantly, at present, RCM is only available in some clinics due to the prohibitively high initial cost of setup (2, $7,8,11,12)$.

Within the scope of dermatology, RCM is most commonly used for diagnosing neoplastic lesions (2). RCM has also been utilized for infestations such as scabies or pediculosis (4-13). As previ- ously stated, crusted scabies is a relatively challenging entity, for which RCM may prove to be particularly helpful in the diagnosis $(2,4,8,9,12)$. Similar to our report, some authors have provided real-time video recordings of $S$. scabiei moving within the skin $(7,8,10)$. Furthermore, Levi et al. described living larvae of the ectoparasite using RCM in a patient with crusted scabies (8). $\mathrm{Ci}$ notti et al. estimated the number of $S$. scabiei mites infesting the entire body surface of a patient with crusted scabies to be approximately 15.8 million, underlining the fact that RCM can be experimentally used to quantify mites and eggs in this highly contagious form of scabies (9). Furthermore, the same team of authors compared videodermoscopy and RCM for diagnosing scabies and concluded that both modalities were highly accurate for this purpose (11). A common denominator of the above-mentioned case reports and studies is that RCM is a valuable technique for diagnosing scabies and offers the chance to monitor the response to treatment by observing the viability of S. scabiei. The latter is an important advantage of RCM given the lack of availability of objective predictors of the response to scabies treatment other than clinical assessment.

\section{CONCLUSION}

Reflectance confocal microscopy may provide a convenient means for a detailed and in vivo visualization of S. scabiei. This technique also allows the lifecycle of the mite to be examined for research purposes and its viability to be assessed to monitor the response to treatment. In the future, RCM may gain widespread application in clinical settings as advances in technology decrease the high initial cost of the devices.

Informed Consent: Written informed consent was obtained from the patient who participated in this case study.

Peer-review: Externally peer-reviewed.

Author Contributions: Concept - M.S.G.; Design - A.V.T.E., B.T.; Supervision - M.S.G.; Data Collection and/or Processing - M.S.G., A.V.T.E., B.T.; Analysis and/or Interpretation - M.S.G., B.T.; Literature Review - B.T.; Writing - M.S.G., B.T.; Critical Review - M.S.G., A.V.T.E., B.T.

Conflict of Interest: No conflict of interest was declared by the authors.

Financial Disclosure: The authors declared that this study has received no financial support.

Hasta Onamı: Yazılı hasta onamı bu çalışmaya katılan hastadan alınmıştır.

Hakem Değerlendirmesi: Dış bağımsız.

Yazar Katkıları: Fikir - M.S.G.; Tasarım - A.V.T.E., B.T.; Denetleme - M.S.G.; Veri Toplanması ve/veya İşlemesi - M.S.G., A.V.T.E., B.T.; Analiz ve/veya Yorum - M.S.G., B.T.; Literatür Taraması - B.T.; Yazıyı Yazan - M.S.G., B.T.; Eleştirel İnceleme - M.S.G., A.V.T.E., B.T.

Çıkar Çatışması: Yazarlar çıkar çatışması bildirmemişlerdir.

Finansal Destek: Yazarlar bu çalışma için finansal destek almadıklarını beyan etmişlerdir.

Video 1. This brief real-time video was captured by reflectance confocal microscopy (Vivascope 3000, Lucid Inc., Henrietta, NY, USA) and demonstrates the movement of the mouthparts, anterior legs, and digestive tract of the mite while it burrows through the skin 


\section{REFERENCES}

1. Falay T, Gürel MS. Uyuz. Turkiye Klinikleri J Dermatol-Special Topics 2017; 10: 143-53.

2. Micali G, Lacarrubba F, Verzì AE, Chosidow O, Schwartz RA. Scabies: Advances in noninvasive diagnosis. PLoS Negl Trop Dis 2016; 10 : e0004691. [CrossRef]

3. Kutlu NS, Turan E, Erdemir A, Gürel MS, Bozkurt E. Eleven years of itching: a case report of crusted scabies. Cutis 2014; 94: 86-8, 95.

4. Uysal PI, Gurel MS, Erdemir AV. Crusted scabies diagnosed by reflectance confocal microscopy. Indian J Dermatol Venereol Leprol 2015; 81: 620-2. [CrossRef]

5. Turan E, Erdemir AT, Gurel MS, Basaran YK. The detection of Sarcoptes scabiei in human skin by in vivo confocal microscopy. Eur J Dermatol 2011; 21: 1004-5.

6. Longo C, Bassoli S, Monari P, Seidenari S, Pellacani G. Reflectance-mode confocal microscopy for the in vivo detection of Sarcoptes scabiei. Arch Dermatol 2005; 141: 1336. [CrossRef]

7. Levi A, Mumcuoglu KY, Ingber A, Enk CD. Assessment of Sarcoptes scabiei viability in vivo by reflectance confocal microscopy. Lasers Med Sci 2011; 26: 291-2. [CrossRef]
8. Levi A, Mumcuoglu KY, Ingber A, Enk CD. Detection of living Sarcoptes scabiei larvae by reflectance mode confocal microscopy in the skin of a patient with crusted scabies. J Biomed Opt 2012; 17: 060503. [CrossRef]

9. Cinotti E, Perrot JL, Labeille B, Vercherin P, Chol C, Besson E, et al. Reflectance confocal microscopy for quantification of Sarcoptes scabiei in Norwegian scabies. J Eur Acad Dermatol Venereol 2013; 27: e176-8. [CrossRef]

10. Lacarrubba F, Verzì AE, Micali G. Detailed analysis of in vivo reflectance confocal microscopy for Sarcoptes scabiei hominis. Am J Med Sci 2015; 350: 414. [CrossRef]

11. Cinotti E, Labeille B, Cambazard F, Biron AC, Chol C, Leclerq A, et al. Videodermoscopy compared to reflectance confocal microscopy for the diagnosis of scabies. J Eur Acad Dermatol Venereol 2016; 30: 1573-7. [CrossRef]

12. Cinotti E, Perrot JL, Labeille B, Cambazard F. Reflectance confocal microscopy for cutaneous infections and infestations. J Eur Acad Dermatol Venereol 2016; 30: 754-63. [CrossRef]

13. Aksu AE, Erdemir VA, Gurel MS, Sarikaya E, Ozkur E. In vivo evaluation of Phthirus pubis with reflectance confocal microscopy. Parasitol Res 2015; 114: 3559-61.[CrossRef] 